\title{
IDENTIFICAÇÃO DOS PROBLEMAS DE ALAGAMENTO NA CIDADE DE CACHOEIRO DE ITAPEMIRIM- ES: ESTUDO DE CASO SOBRE A ÁREA CENTRAL.
}

\begin{abstract}
Altair Carrasco De Souza - altaircarrasco@ hotmail.com
Universidade Federal de Viçosa, Programa de Pós-Graduação em Engenharia Civil.
\end{abstract}




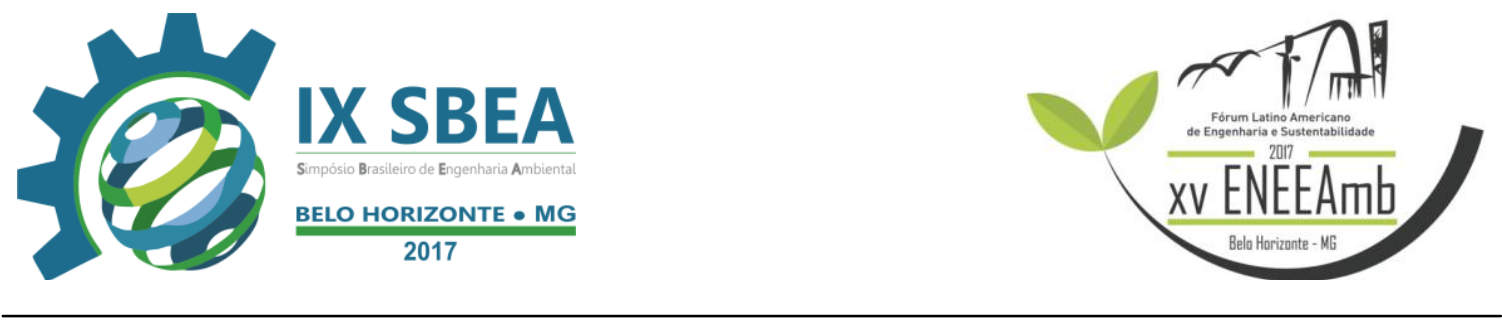

\section{RESUMO}

O crescimento urbano, especialmente nos países em desenvolvimento é sinal de maior dinamismo econômico, entretanto vem acompanhado de problemas de difícil gestão. O município é caracterizado por estar no meio de um vale montanhoso e tem relevo predominantemente acidentado, assim possui uma heterogeneidade de paisagens naturais em seu tecido urbano, a produção do espaço urbano aparece em diferentes formas de uso do solo. Urbano. O solo urbano apresenta vários usos que ocasionam em inúmeros riscos ambientais, principalmente os alagamentos, deslizamentos e inundações que estão relacionados a eventos pluviométricos intensos. Os equipamentos de drenagem urbana do município apresentam ineficiência para a recepção e escoamento de grandes volumes de água em curto períodos de tempo. O ordenamento territorial através do planejamento ambiental e urbano, são instrumentos que atuam diretamente para a criação de cidades resilientes.

Palavras-chave: Uso e Ocupação do Solo, Urbanismo, Gestão de Cidades, Resiliência

\section{INTRODUÇÃO/OBJETIVO}

Há tempos, a sustentabilidade, a consciência ambiental e os problemas relacionados à degradação do meio ambiente vêm se tornando a pauta de discussão em diversos setores da sociedade. A utilização intensa dos recursos naturais gerou, ao longo dos anos, impactos negativos nos meios físicos e bióticos, alterando em alguns casos, de forma significativa, o equilíbrio ambiental. Segundo (GORSKI, 2010, p. 62) “a redução da vegetação de porte arbóreo, associada à expansão da pavimentação, resulta em volume crescente de água de escoamento superficial. A organização de poder político dominante e as diversas maneiras de aplicação do capital, como investimentos em imóveis e terrenos são, às vezes, os mais preferidos dos detentores do capital em função da manutenção da qualidade do meio físico. Conforme Rinaldo (2014,p 11), “associado a estes fatores provocados pelo homem e o alto índice de pluviosidade em um pequeno período de tempo, como já foi colocado, contribui para o alagamento, ainda mais em um país como o Brasil, onde as chuvas são constantes na maior parte do país”. 
A cidade se desenvolveu em um grande vale, tendo uma rede hidrográfica com pequenos cursos hídricos e um rio de grande porte considerando as características regionais, comumente ocorrem alagamentos e inundações em algumas regiões da cidade durantes dos períodos de elevados índices pluviométricos. O termo alagamento é usado para identificar processos que acarretam na deposição momentânea de águas em um dado local por problemas de deficiência no sistema de drenagem superficial. (SANTOS, 2010, p.30)

As áreas com declividade acentuadas, são ocupadas quase que em totalidade. $\mathrm{O}$ desenvolvimento urbano através de superfícies impermeáveis e canalização do escoamento pluvial aumenta de forma significativa o escoamento superficial (TUCCI,2008).

O espaço geográfico se caracteriza como sendo o lócus onde se materializam as tramas que favorecem os grupos economicamente dominantes. O tecido espacial que parece absorver naturalmente os impactos do uso inadequado do solo urbano, por ora reflete em problemas que são difíceis de serem minimizados através de políticas públicas.

\section{METODOLOGIA}

A escolha da área central se deu por apresentar o local com a maior atividade comercial do município, por consequência o maior fluxo de pessoas durante a semana e ser sede do poder político. A pesquisa foi embasada no mapa de inundações apresentado no plano diretor municipal de 2010, com dados disponibilizados pela Coordenadoria Municipal de Defesa Civil de Cachoeiro de Itapemirim e através informações vinculadas pelas mídias locais. Foram realizadas visitas aos locais caracterizados para a verificação dos equipamentos de drenagem local.

\section{RESULTADOS E DISCUSSÃO}

O centro da Cidade de Cachoeiro de Itapemirim está localizado em limite com a margem direita do Rio Itapemirim, objeto geográfico norteador da formação histórica do núcleo urbano, na relação espaço - tempo esse fator trouxe consequências na 


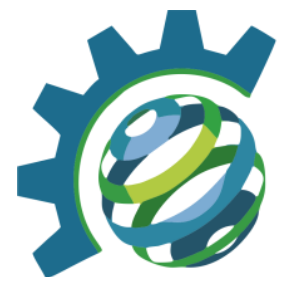

dinâmica das águas urbanas, ocasionando em problemas de alagamentos e inundações quando da ocorrência de índices pluviométricos de media a alta intensidade. O limite esquerdo do centro faz divisa com bairros que apresentam topografia acidentada, os mesmos apresentam cursos d'agua canalizados, intensa urbanização e sistema de drenagem urbana ineficiente a demanda local.

A morfologia da construção do espaço urbano central se deu me maneira desordenada, não apresentando um eixo e nem um plano urbanização. A urbanização desordenada em grande maioria não obedece às particularidades do meio físico, ocupando espaços como topos de morros e leitos de inundação. Quando ao índice de urbanização pode-se caracterizar á região como urbanizada,100\% das ruas pavimentadas e $95 \%$ dos terrenos ocupados por habitações e/ou comércio, a área verde é extremamente deficiente, restando apenas alguns resquícios de nas calçadas e residências.

O posicionamento da região central encaixada dentro de uma área de planície, que de um lado, faz divisa com o principal corpo hídrico regional e de um outro com bairros de topografia acentuada, acarretando em alagamentos constantes, devido convergimento das águas para a área central. Por via, e percebido em campo que os problemas de alagamento são oriundos do déficit de drenagem, devido a ineficiência dos equipamentos de drenagem urbana.

Na divisa do centro com o Bairro Gilberto Machado encontra- se um ponto de alagamento (Figura 01), o local é receptor das águas pluviais no bairro Gilberto Machado que apresenta cota topografia elevada. O ponto analisado está localizado em sopé ao relevo, a área não apresenta equipamentos de drenagem suficientes para captação e dissipação do volume de água pluvial recebido, sem que não haja acumulação de água. 

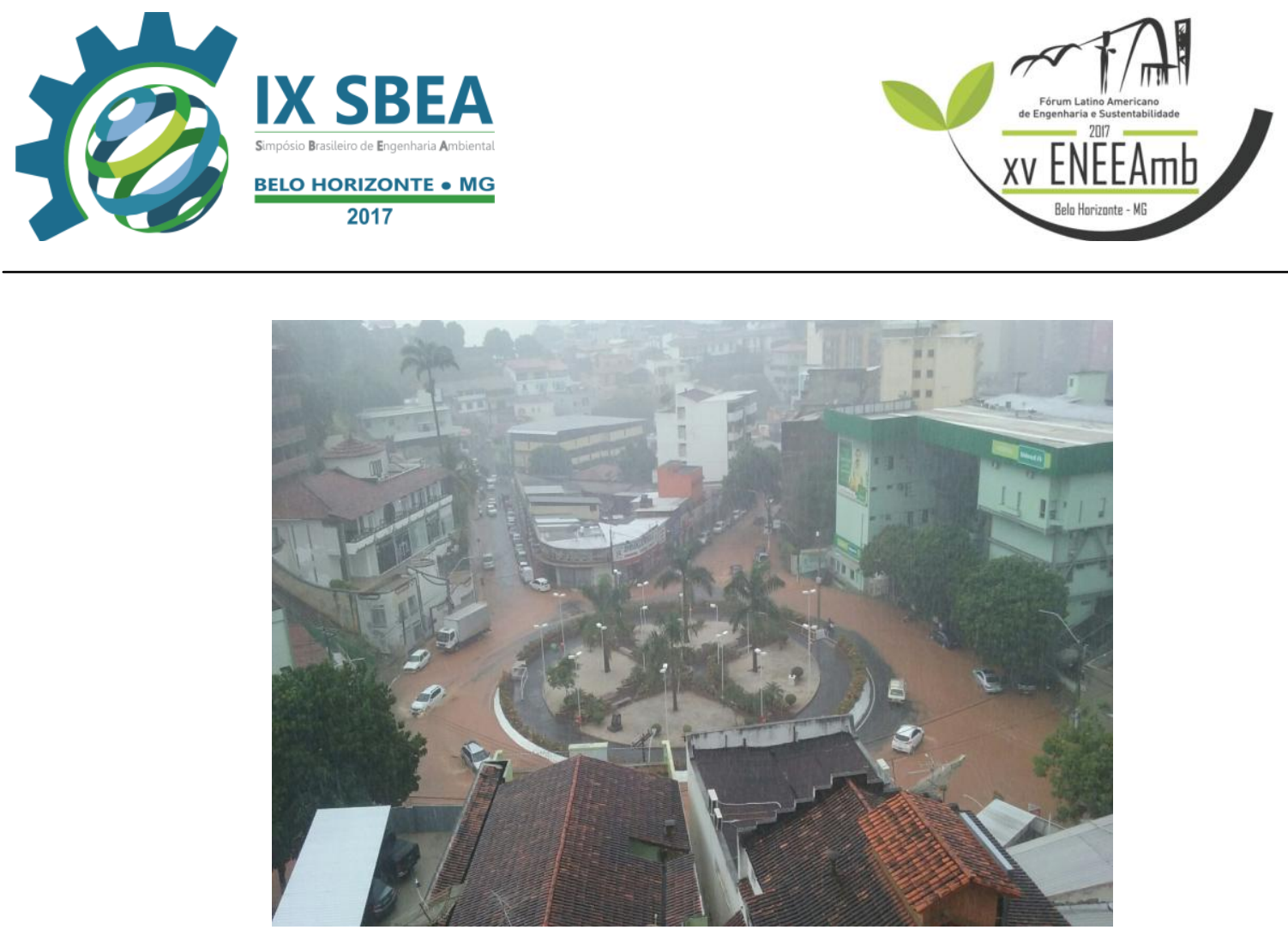

Figura 01 - Ponto de alagamento na divisa do Bairro Centro com o Bairro

Gilberto Machado

Fonte: http://www.jornalfato.com.br/site/conteudo.asp?codigo=19531

Na Rua Jeronimo Monteiro (Figuras 02 e 03) o alagamento ocorre devido ao local ser o ponto receptor das águas pluviais convergentes dos bairros a esquerda circunscritos ao centro. Esse Ponto recebe por gravidade águas do ponto de alagamento descrito anteriormente. Ao percorrer o perímetro da rua percebe que os equipamentos de drenagem urbana, tal como, os bueiros(caixa com grelha e bocas - de - lobo),além da precariedade, apresentam falta de limpeza externa um lixo 

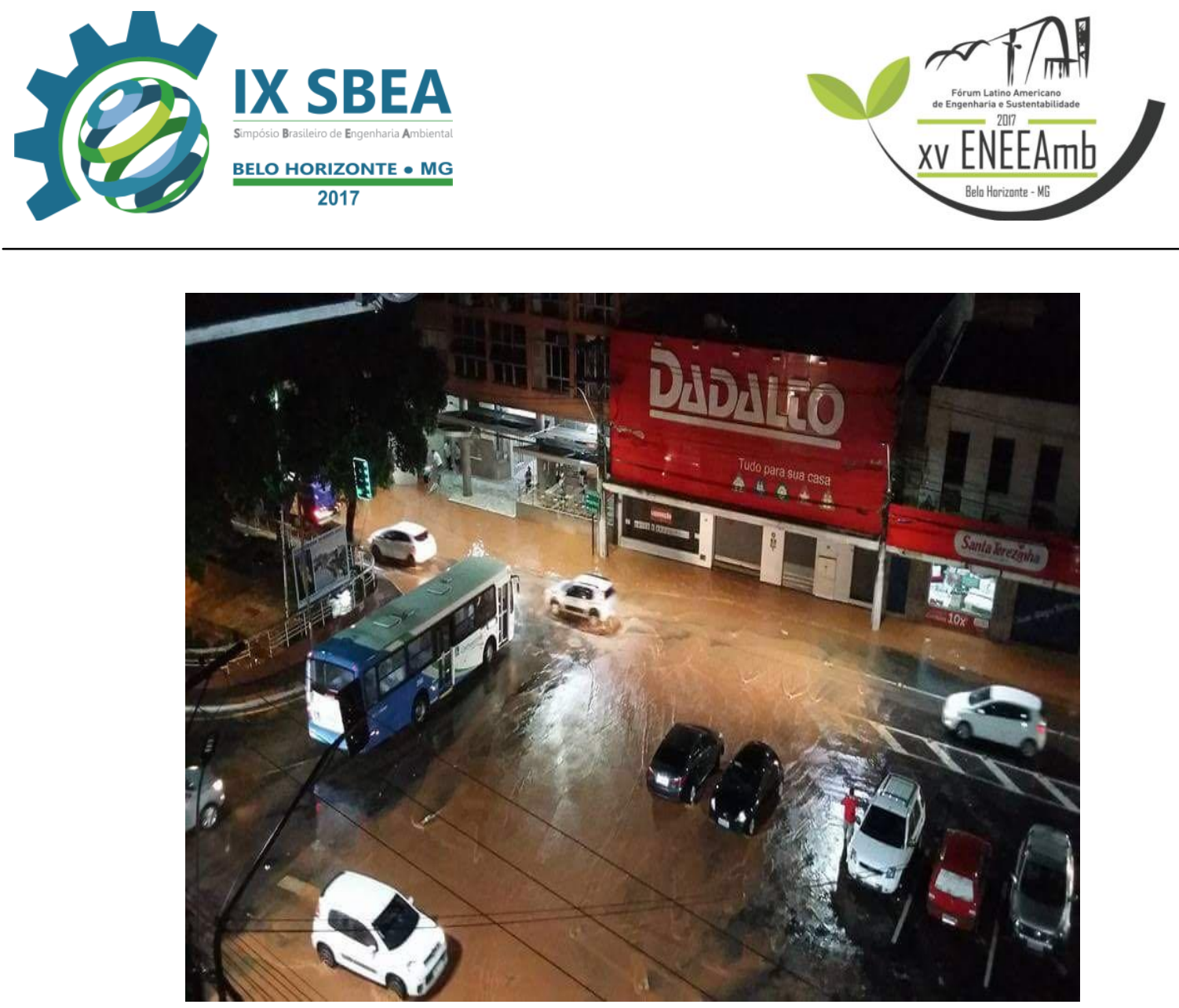

Figura 02 - Ponto de alagamento na Rua Jeronimo Monteiro

Fonte: http://www.jornalfato.com.br/site/conteudo.asp?codigo=19531

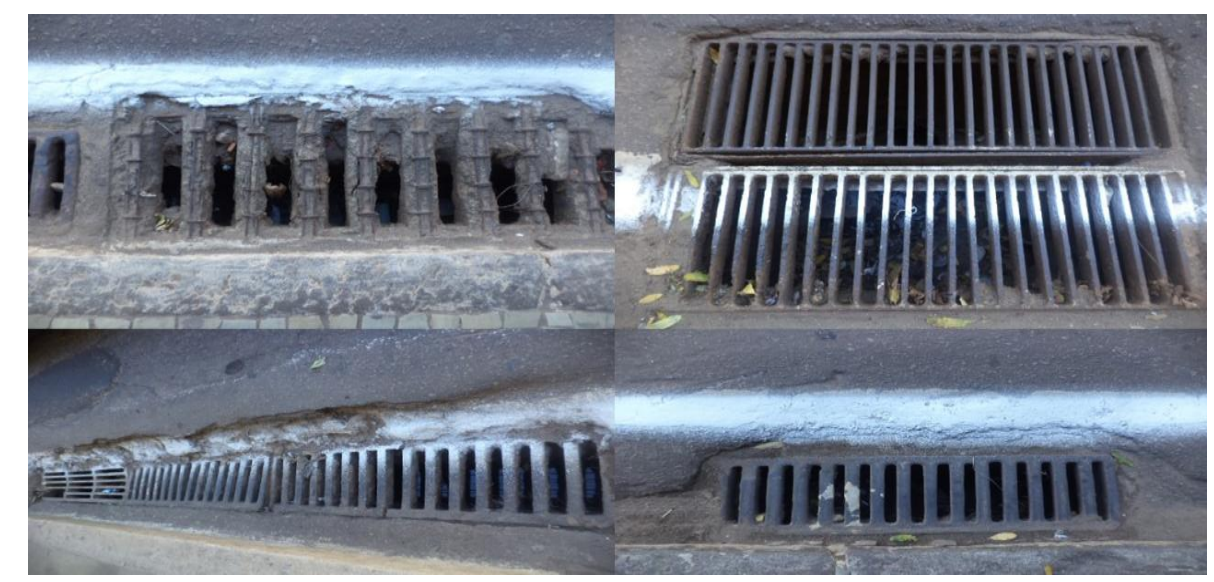

Figura 03 - Equipamentos de Drenagem Urbana encontrados Ponto de alagamento da Rua Jeronimo Monteiro

Fonte: http://www.jornalfato.com.br/site/conteudo.asp?codigo=19531

$\mathrm{Na}$ área avenida denominada "Beira rio" encontram-se três pontos de alagamento. O primeiro fica localizado embaixo da cabeceira da ponte de ferro (Figura 

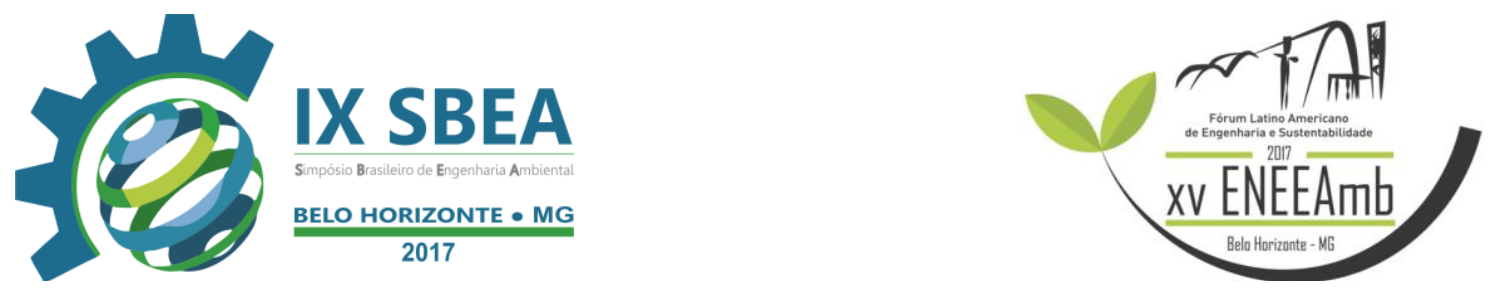

04).O alagamento ocorre devido ao acumulo de água superficial devido à falta de escoamento por ineficiência dos equipamentos de drenagem existentes ( Figura 05).

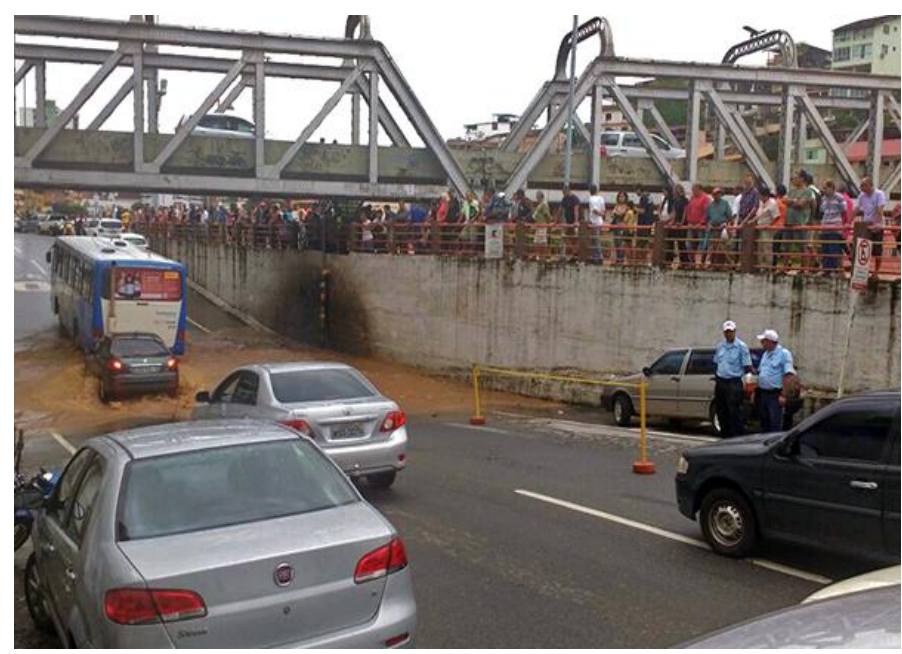

Figura 04 - Ponto de alagamento na Avenida Beira Rio (Ponte de Ferro).

Fonte: http://www.folhadoes.com/noticia/2016/12/15/acompanhe-as-imagensdo-estragos-causado-pelas-chuvas-em-cachoeiro-es.html

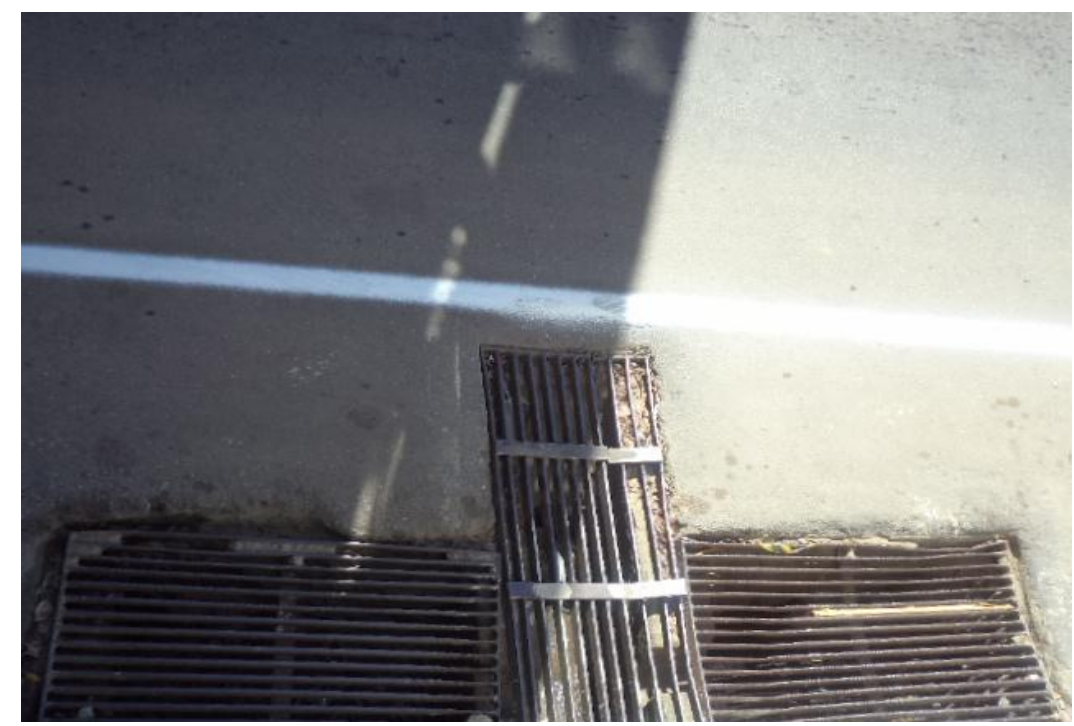

Figura 05 - Equipamento de drenagem encontrado no ponto de alagamento na Avenida Beira Rio( Ponte de Ferro).

Fonte: O autor (2017) 


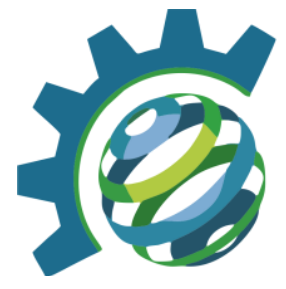

O segundo ponto(Figura 06) de alagamento na Avenida Beira Rio (Praça de Fatima),o problema ocorre devido a inexistência e ineficiência dos equipamentos de drenagem no ambiente e ao redor do ambiente observado.

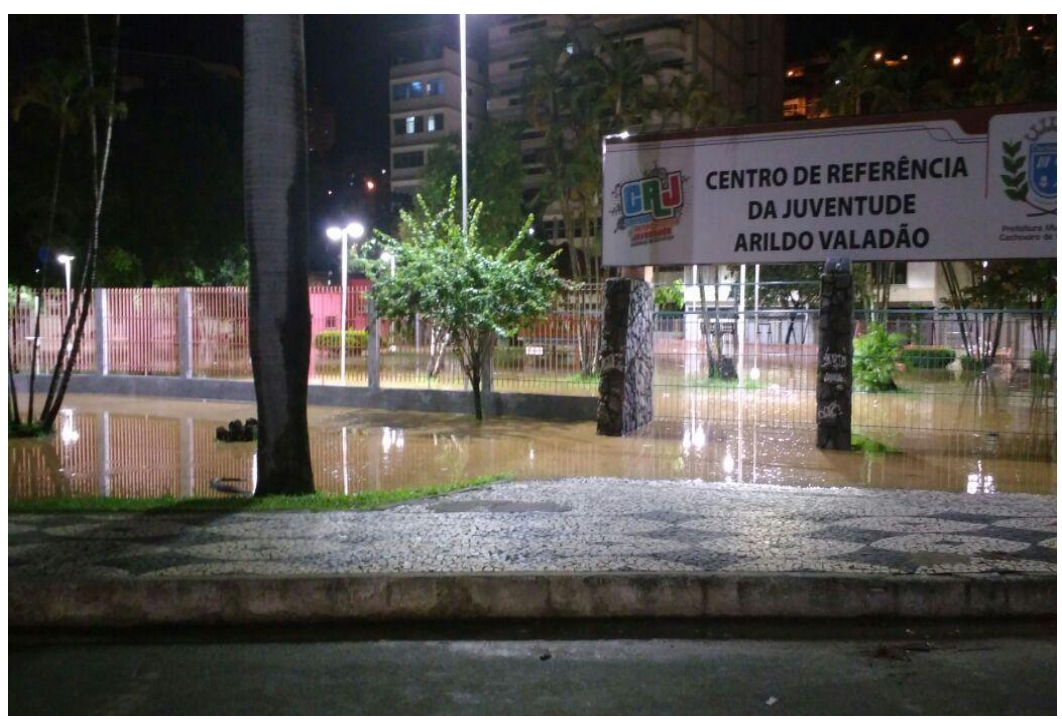

Figura 06 - Equipamento de drenagem encontrado no ponto de alagamento na Avenida Beira Rio(Praça de Fatima).

Fonte: http://www.folhadoes.com/noticia/2016/12/16/veja-alguns-pontos-dealagamento-cachoeiro-es.html

O terceiro ponto (Figura 07) de alagamento na Avenida Beira Rio ocorrem devido a entrada de água fluvial no sistema de galerias pluviais em dias épocas de elevação no nível do curso hídrico devido ao aumento do volume recebido das águas de todo a bacia hidrográfica do Rio Itapemirim. Ou devido ineficiência dos equipamentos de drenagem urbana local. Nos períodos de altos índices pluviométricos as galerias recebem um montante maior de deflúvios e com a entrada de água do rio nas galerias, a mesma não suporta tal volume, ocasionando no refluxo de água pelas bocas de lobo. 

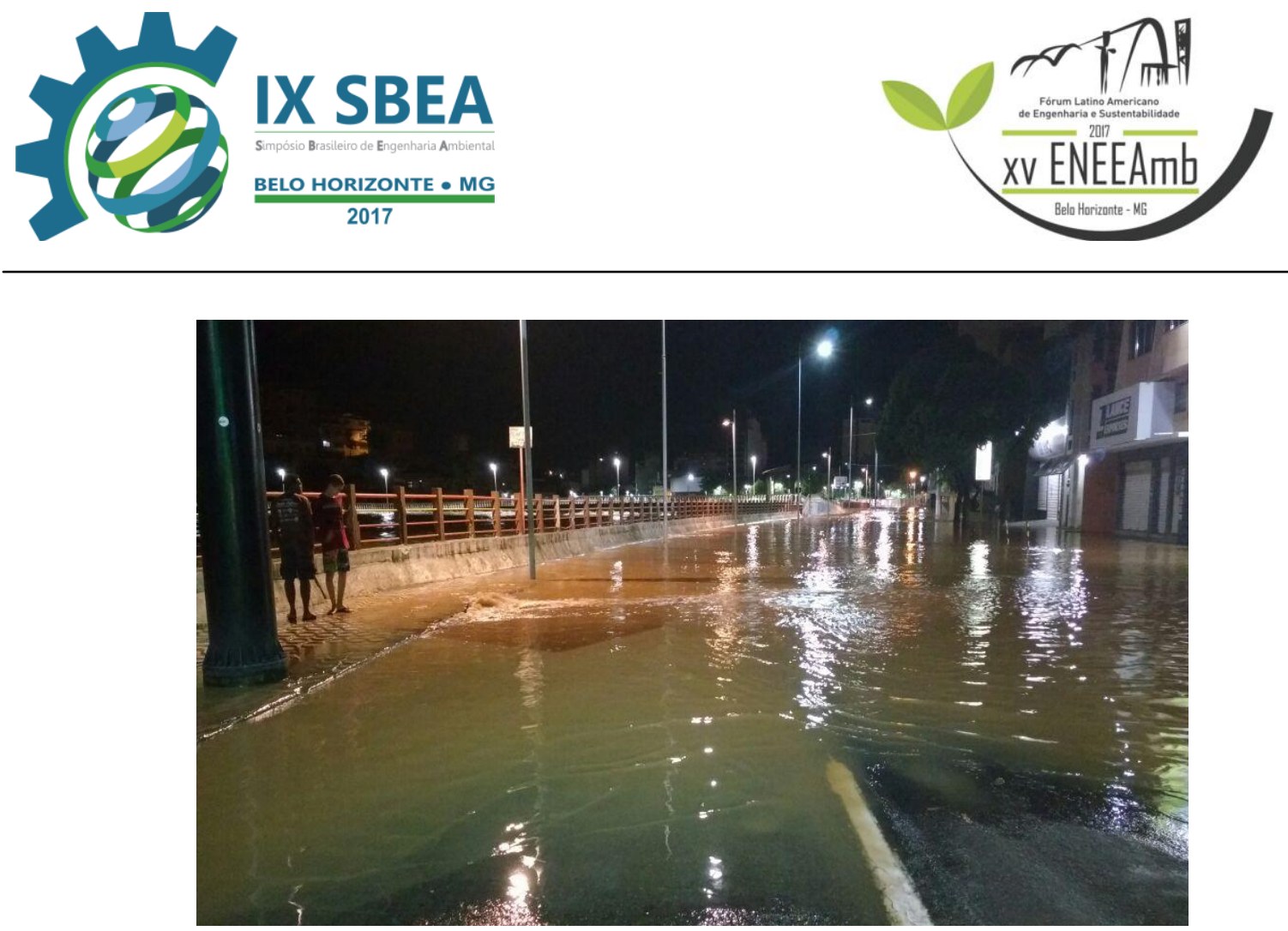

Figura 07 - Ponto de alagamento na Avenida Beira Rio (a o longo da via).

Fonte: http://m.folhadoes.com/noticia.php?id=30340\&titulo=veja-algunspontos-de-alagamento-cachoeiro-es

\section{CONCLUSÕES/RECOMENDAÇÕES}

$\mathrm{Na}$ área central do município de Cachoeiro de Itapemirim - ES foram identificados cinco pontos de alagamento e que atingem direta e indiretamente 12 vias de acesso. Esses problemas são observados nos períodos de dezembro a março, quando incidem sobre o município e sobre a bacia hidrográfica maiores índices pluviométricos.

As principais causas dos alagamentos nos pontos identificados são: a impermeabilização do solo, o déficit do sistema de drenagem atual através da precariedade ou inexistência dos equipamentos de drenagem urbana e a localização dos mesmos. As principais consequências dos alagamentos na área central do município são: alteração do regime de trafego de veículos e perdas econômicas devido a entrada de água nos comércios e residências. Para a minimização e mitigação desses impactos são recomendados a readequação e requalificação dos equipamentos de drenagem urbana existentes e a criação de um sistema de retenção de água no Bairro Gilberto Machado. 


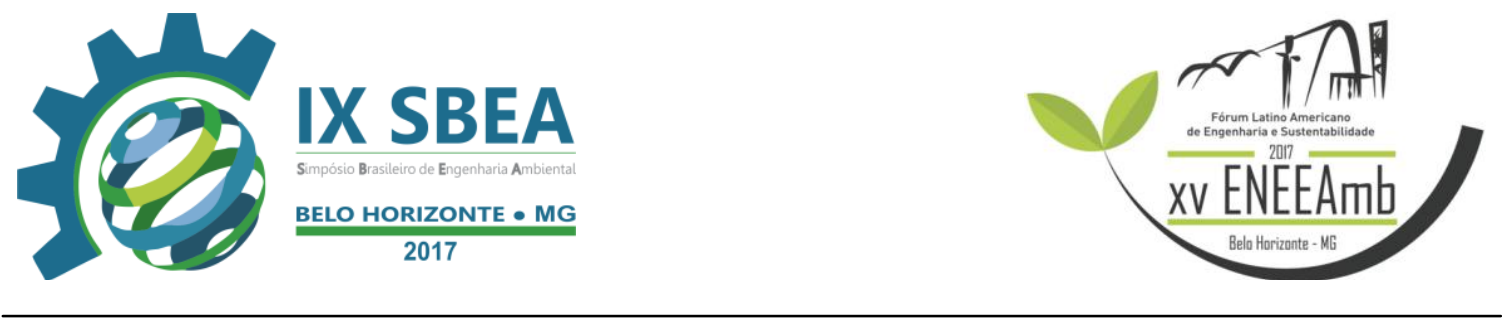

\section{REFERÊNCIAS BIBLIOGRÁFICAS}

GORSKI, Maria Cecília Barbieri. Rios e cidades: ruptura e reconciliação. São Paulo: Senac, 2010.

RINALDO, Sandra Anelí Mendes. Alagamento urbano no centro histórico de londrina - pr: nos anos de 2009, 2010 e 2011. 2014. 74 f. Trabalho de Conclusão de Curso em Geografia Universidade Estadual de Londrina, Londrina, 2014.

SANTOS, Flávio Augusto Altieri dos.Alagamento e inundação urbana: modelo experimental de avaliação de risco. 2010. Dissertação (Mestrado em Ciências Ambientais) - Universidade Federal do Pará, Belém.

TUCCI, Carlos E. M. Águas urbanas. Estudos Avançados, São Paulo, v.22, n.63, jun. 2008. Disponível em: Acesso em: 05 abril. 2017. 